\title{
Sustainability Profile of Islamic Banking Industry: Evidence from World Top Five Islamic Banking Countries
}

\author{
Amin $\operatorname{Jan}^{1} \&$ Maran Marimuthu ${ }^{2}$ \\ ${ }^{1}$ Department of Management and Humanities, Universti Teknologi Petronas, Malaysia \\ ${ }^{2}$ Faculty of Management and Humanities, Universti Teknologi Petronas, Malaysia \\ Correspondence: Amin Jan, Department of Management and Humanities, Universti Teknologi Petronas Malaysia. \\ E-mail: Amin_jan_khan@yahoo.com
}

Received: February 5, 2015

Accepted: February 12, 2015

Online Published: April 25, 2015

doi:10.5539/ijef.v7n5p125

URL: http://dx.doi.org/10.5539/ijef.v7n5p125

\begin{abstract}
The main purpose of this paper is to analyze the economic sustainability of Islamic banking industry in the top five Islamic banking countries by global Islamic banking assets i.e. Iran, Saudi Arabia, Malaysia, Kuwait, and U.A.E. This paper applied Altman model on the selected Islamic banks with the objective to evaluate their economic sustainability, ANOVA and Regression tests are applied to examine the significance and correlations of independent variables with bankruptcy. From the selected sample Saudi Arabian Islamic banks top the sustainability profile list while Malaysian banks reserved the last place. The overall bankruptcy rate of Islamic banks is recorded 53 per cent, while, Malaysian Islamic banks registered the highest bankruptcy rate of 89 per cent, and Saudi Arabian banks retained the lowest bankruptcy rate of 29 per cent. Moreover profitability ratio is found to be insignificant with sustainability exposure. The model used in this study required retained earnings, while retained earnings is directly linked with the age of firm. However, majority of the Malaysian and Kuwaiti Islamic banks are incorporated in mid 2000, the small age of these banks lead towards their lower or negative retained earning, which ultimately reduced their sustainability rating in the evaluation process. The analysis here is viable for drawing the attention of researchers and practitioners towards the deteriorated economic sustainability of Islamic banking industry. This study also urge to develop a separate bankruptcy continuum model for Islamic banking industry, therefore, this study will also serve as a launching pad in the process of developing that model.
\end{abstract}

Keywords: financial characteristics, performance indicators, bankruptcy, sustainability, Islamic banking industry

\section{Introduction}

After the subprime crisis of (2007-2008) considering sustainability is no more optional. Now the banks have to prove that their business model is sustainable and have to demonstrate practically that their business model is contributing towards economic growth and stability of the country. Leon (2001) said that the percentage of organizations that achieves financial sustainability is still very low. However, the debate on sustainable banking has already been started. In line of that, the Global Alliance for banking on values the GABV (Note 1) (an independent network of banks) started its operation in May 2011 with a motive to provide sustainable banking. The term sustainable banking is a philosophy which underpins every thing about banking industry i.e. from only being profitable towards achieving social and environmental objective as well, literally termed as CSR the corporate social responsibility.

Banking industry due to its intermediary role in the economy accounts for achieving the sustainable economic development of the country (Jeucken et al., 1999; Brown, 2003; Safiullah, 2010). Failure of banking industry is not a threat only toward the deterioration of country's domestic economic performance and growth, but it is additionally a threat to the international financial scheme and international economic development up to an immensely colossal scale, same like the aftershocks witnessed by world financial scheme with the collapse of large world banks like the Lehman brother's investment banking, Citigroup New York, and Anglo Irish bank etc. Since the banking activities effects the overall world economic condition, therefore regular monitoring of the banking activities is obligatory (Rashid et al., 2009).

Although banks have their own sustainability maintaining techniques and milestones, the common example is 
about CAMELS rating technique, i.e. capital adequacy, asset quality, management quality, earnings, liquidity and sensitivity to market risk. Kumar et al. (2008) said that the CAMELS rating is the best and precise way of monitoring onsite banking performance. Beside the bank's internal performance evaluation methods some outside evaluators like the FSB (Note 2) (financial stability board) are also monitoring and offering surveillance to the financial institutions for securing better sustainability. Despite of all the internal and external monitoring process and techniques for achieving strong sustainability by banks, still banking distresses and deterioration in banks financial performances are witnessed.

In (2007-2008) financial crisis major Islamic banks i.e. Dubai Islamic bank and Noor Islamic bank of Dubai, Kuwait finance house of Kuwait, al-Hilal bank of Abu Dhabi, and al-Rajhi bank of Saudi Arabia were affected by the problem of liquidity (Husna et al., 2012). Yudistra (2004) said that Islamic banks performance was also affected by the financial crisis of (1998-1999). However, on the other hands many theoretical studies has shown that Islamic finance can reduce the affect of financial crisis (Derbel et al., 2011). Magd et al. (2014) said that Islamic financial industry was not fully immune to the global economic downturn, as Islamic banks lost heavily in real estate and Sukuk, however, the overall impact was limited. The financial distresses and deterioration in banking financial performances are raising many questions on the prudential regulations and sustainability strategies of the banks. Therefore, different researchers are developing and proposing different models and strategies for diagnosing and avoiding bankruptcy and maintaining strong sustainability.

In current banking industry Islamic and conventional banks are weighted as two rivals alongside in many Muslim and even in non-Muslim lands, maintaining strong sustainability is vital to the existence profile of both the parties. However the existing market share of Islamic banks does not have a significant impact on the financial strengths of conventional banks and large Islamic banks are financially unstable compared to large conventional banks (Cihak et al., 2010). Beside that, the over all Islamic banking and finance industry retains $1.5 \%$ of the total global banking assets only (Beck et al., 2013). Isaac et al., (2014) said that Islamic banking industry retains less than $1 \%$ of the global banking assets. Therefore, the current scenario is extra urging Islamic banking industry to maintain extra strong sustainability for their business continuation.

Beside the low market share of Islamic banks the prudential regulations of Islamic banks are also not very satisfactory (Cihak et al., 2010). Faisal Islamic bank in the UK was closed because of regulatory problem. Likewise, in the Bahamas Al Taqwa bank also ceased its operation because of inefficient prudential regulation (Husna et al., 2012). The reference of the current problem associating with Islamic banks and the going concern concept of accounting has sanctioned all the interested and concerned parties associated with Islamic banks to evaluate its sustainability. As the going concern concept is vital for both the internal and external stake holder of the firm (Mossman et al., 1998).

Table 1. Share of Islamic Banks (IB) and Conventional Banks (CB) of the global Islamic banking assets (\%)

\begin{tabular}{llll}
\hline S.N & Country & IB share & CB share \\
\hline 1 & Saudi Arabia & 53.0 & 47.0 \\
2 & Malaysia & 20.0 & 80.0 \\
3 & U.A.E & 17.0 & 83.0 \\
4 & Kuwait & 31.0 & 69.0 \\
5 & Qatar & 24.0 & 76.0 \\
6 & Turkey & 06.0 & 94.0 \\
7 & Bahrain & 27.0 & 73.0 \\
8 & Indonesia & 05.0 & 95.0 \\
9 & Iraq & 25.0 & 75.0 \\
10 & Yemen & 30.0 & 70.0 \\
11 & Egypt & 04.0 & 96.0 \\
12 & Algeria & 01.0 & 99.0 \\
13 & Tunisia & 02.0 & 98.0 \\
14 & Lebanon & 01.0 & 99.0 \\
15 & Syria & 04.0 & 96.0 \\
16 & Jordan & 12.0 & 88.0 \\
17 & Average Share & $\mathbf{1 6 . 0}$ & $\mathbf{8 4 . 0}$ \\
\hline
\end{tabular}

Source: World Islamic bank competitiveness report year 2011/2012 and 2013/2014. 
Table 1 indicates the share of Islamic and conventional banks in major Muslim countries based on the total banking assets. Saudi Arabia and Kuwait registered significant ratios on Islamic banking operations which contributed about half of the total banking assets. Meanwhile, Malaysia, Qatar and Bahrain emerged as second tier Islamic Banking countries as their Islamic Banking assets valued at about 20 per cent of the total banking assets. On average, the ratio between IB and CB is recorded at 16:84 in major Muslim countries.

Table 2. Compound annual growth rate (assets) \% of Islamic banks

\begin{tabular}{llll}
\hline Country & CAGR (2006-2010) \% & CAGR (2008-2012) \% & Decline \% \\
\hline Saudi Arabia & 19.0 & 11.0 & 08.0 \\
UAE & 16.0 & 14.0 & 02.0 \\
Kuwait & 22.0 & 06.0 & 16.0 \\
Malaysia & 19.3 & 20.0 & 0.00 \\
Qatar & 39.0 & 31.0 & 08.0 \\
Bahrain & 22.0 & 02.0 & 20.0 \\
Average & $\mathbf{2 2 . 8}$ & $\mathbf{1 4 . 0}$ & $\mathbf{0 9 . 0}$ \\
\hline
\end{tabular}

Source: World Islamic bank competitiveness report year 2011/2012 and 2013/2014.

Table 2 shows the CAGR of major Islamic banking countries over the period 2006-2012. A significant decline in CAGR of Islamic banks is evident from Table 2 above. It seemed that some of the major Islamic banking countries registered a significant decline in their CAGRs over the period 2006-2012. For instance, Bahrain registered a significant drop by 20 per cent in its CAGR, followed by a 16 per cent drop by Kuwait. In view of this, the current problems associated with Islamic banks provide the substantial reason to question and evaluate the economic sustainability of Islamic banks.

In this study, key performance indicators are used to evaluate the bankruptcy of Islamic banks, however, the bankruptcy is used as proxy for measuring economic sustainability. Because it's understood that bankrupt banks has low economic sustainability and non-bankrupt firms are generally considered more sustainable. Secondly, in failing firms bankruptcy evaluation provides the early warning signs to the representative authorities to take corrective steps in order to avoid bankruptcy and maintain strong sustainability (Altman 1984; Telmoudi et al., 2011).

\subsection{Social Sustainability Dimensions for Banks}

This deals with managing the impact of banking activities on the society. In this aspect the bank needs to develop ethical standards while granting loans to individuals, small or large businesses, and to public sectors bodies. It also deals with the involvement of bank's staff in community's' fund raising and philanthropic work.

\subsection{Environmental Sustainability Dimensions for Banks}

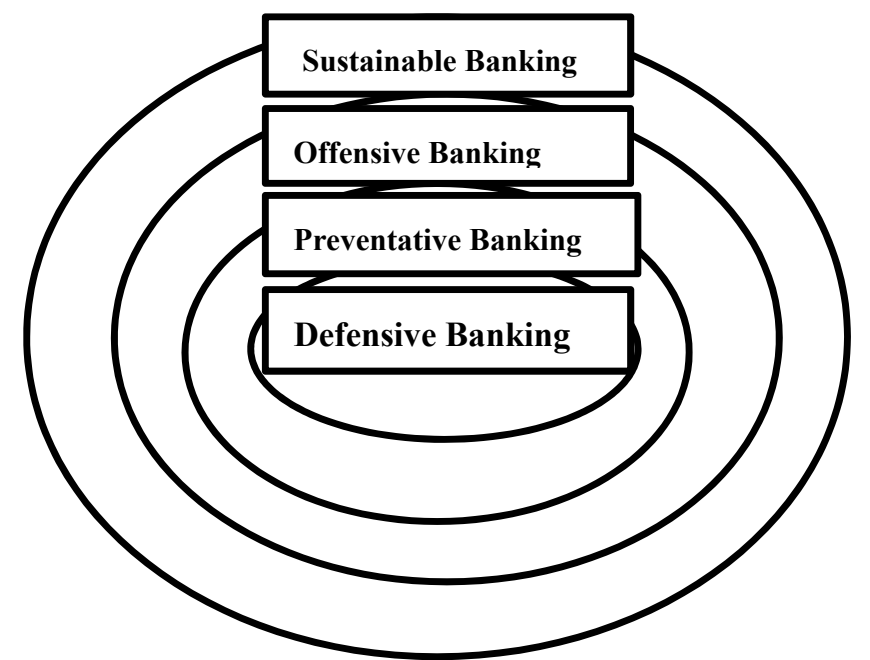

Figure 2. Typology of banking and sustainability development

Source: (Jeucken et al., 1999). 
It deals with minimizations of banks activities which have a negative impact on the environment, at the same time it also deals with refusing of loans to such organizations whose actions cause negative and harmful impact on the environment. Furthermore, it also deals with granting funds to those organizations who are engaged in renewable energy products. Jeucken et al. (1999) divide the accomplishment of environmental sustainability in four steps starting from defensive banking till achieving sustainable banking. There are some standard performance indicators identified by the GRI (Note 3) (global reporting initiative) for measuring environmental, social and economic sustainability, however social and environmental sustainability is beyond the scope of this study.

\subsection{Economic Sustainability Dimension of Banks}

Economic sustainability of banks is a broader concept which covers the micro, macro, and structural factors. In general, economic sustainability refers to the business ability of keeping its high earnings and maintaining business operations successfully in the long run. Maintaining economic sustainability in general deals the following queries.

1) where is the business standing today?

2) where is the business going?

3) how is the business going to get there?

4) evaluating and streamlining key policies i.e. profit, monetary value, leverage, liquidity, productivity etc.

Different businesses have different sustainability strategies according to the different nature of business working, like profit and nonprofit organizations, manufacturing and non-manufacturing organizations etc. Therefore sustainability measurement and it's meaning differ from organization to organization (Leon, 2001).

\subsection{How to Measure Economic Sustainability?}

Keeble et al., (2003) said that internationally recognize economic indicators may play a significant role in identifying the key performance indicators for a particular organization. Once the key performance indicators are identified, it may help in developing an appropriate model for organization sustainability measuring. Rennings et al., (1997) argued that sustainability measurement can be accomplished by categorizing sustainability in to two sets, strong sustainability, and weak sustainability.

\section{Scope of This Study}

The scope of this study is confined to evaluate the economic sustainability of Islamic banking industry in world of top five Islamic banking countries.

\section{Islamic Banking Globally}

Islamic finance is composed of four components i.e. (Islamic banking), (Sukuk), (Islamic funds), and (Takaful). Islamic banking posses $80.9 \%$ share of Islamic finance followed by $13.5 \%, 4.5 \%$, and $0.8 \%$ by Sukuk, Islamic funds and Takaful respectively (Global Islamic Forum, 2012). The focus of this study is only in the Islamic banking side. The organization of Islamic cooperation (OIC) operationalized Islamic development bank (1973) and Dubai Islamic bank in (1975). Those initiatives served as the launching pad for Islamic banking industry on the larger scale. The role of Islamic development bank is to promote Islamic banking in OIC countries by providing funds and to achieve social \& economic development within the sharia laws, literally known as the corporate social responsibility CSR.

The initial growth of Islamic banking industry took place in the South East Asian countries; however in the 1990's the growth weight shifted towards the Gulf countries. According to Iqbal et al. (2005) the GCC rejoin held $74 \%$ of the global Islamic banking share in 2002. The main reason behind it was the shift of money by Muslims countries to GCC countries after the event of 9/11. (Chenguel, 2014; Usman et al., 2012) said that, started on a small scale Islamic banks broadened its network to more than sixty countries of the world. As a result large international conventional banks like BNP Paribas, Citicorp, and Commerzbank have started their separate outlets that offer Shariah compliance products (Olson et al., 2008).

In the past four decades Islamic banking riffed successfully across the world not only in number but also in size. States like Iran and Sudan has changed their entire banking system to Islam. Abdullah et al. (2012) said that Islamic banking is growing popular in non-Muslim nations as well. The first Islamic bank incorporated in non-Muslim country was Islamic bank of Britain, it started its operation in august 2004 (Chong et al., 2009).

\subsection{Iran}

Islamization of the banking system in Iran took place after the Iranian revolution of 1979. On 7th-june-1979 
government legitimized the nationalization of banking industry. Country's 34 banks were merged into 9 banks, consisting of 6 commercial and 3 specialized banks. The term "Interest" was replaced with $4 \%$ "maximum service charges" \& 4-8 \% "guaranteed minimum profit. Further more the interest on deposit was substituted to guarantee minimum profit (Anwar, 1992).

These steps were not sufficient to bring the fundamental change in the banking industry and in the economy of Iran. Therefore the law of "Interest-free-banking' was introduced on 21st-March-1984 with different modalities of financing, i.e. (Qard-al-Hassan, Mudarabah, Muzariah, Mosaqaat, Gala, \& Anwar, 1992). Now Iran is the market leader in the global Islamic banking asset shares.

\subsection{Saudi Arabia}

In the early 1970's Islamic banking was nearly unheard, a conference on Islamic economic held in the early 1970's organized by the members of the King Abdul Aziz university in Makah Saudi Arabia. Due to their devoted work of initiating Islamic banking, the pioneer Islamic bank with the name of Islamic development bank in Jeddah Saudi Arabia started its operations in 1973, followed by 'Dubai Islamic bank' in 1975.The purpose of the IDB is to ascertain the social and economic progress in the OIC countries. According to a new horizon report (2008) IDB provided 10 billion dollars poverty alleviation funds, in the member countries for improving the education system, health system, eliminate poverty, and for women empowerment. Saudi Arabia contributed 1 billion dollars to the total fund of 10 billion by IDB.

Besides poverty alleviation funds, IDB initiated various other developments and technical projects in the member countries. Saudi Arabia is the major shareholder of IDB with 28\%, followed by Libya and Iran with 12 and $9 \%$ respectively. OIC has started many financial subsidiaries and affiliates across the world in compliance with Shariah law, e.g. the general council for Islamic banks and financial institution in Bahrain, Islamic Chamber of commerce and industry (ICCI) headquartered in Pakistan, Islamic Fiqh Academy in Jeddah, the research center of Islamic history culture and Art in Turkey (New Horizon, 2008).

Shariah supervisory board in Saudi Arabia is responsible for monitoring and legitimizing any new goods and services offered by Islamic banks under Shariah law. This board is very much independent as compared to that of Malaysia, Pakistan and other countries, where such boards are bound to abide by the central banks. In Saudi Arabia the major challenges and problem faced by Islamic banking and the overall banking industry is the strict rule and regulation imposed by Saudi Arabian monetary agency SAMA (Note 4). The regulations which were introduced in 1970 are still followed largely by SAMA, although little relaxation took place in 2003 as SAMA allowed some of the new foreign banks to start its operation in the country. However licensing of foreign banks was again suspended temporarily by SAMA.

The major opportunities lies in the progress of Islamic banks in Saudi Arabia is the large oil reserves, as some successful projects in the oil fields brought Islamic banks further a level up. Saudi Arabia was the third largest player in the global Islamic Sukuk market with 11\% in 2007 (New Horizon, 2008).

\subsection{Malaysia}

The concept of Islamic finance in Malaysia was noted earlier 1n 1969, with the operation of an Islamic saving Investment institution on domestic level, known as the Pilgrims Management and Fund Board Lembaga Tabung Haji in 1969 (Kaleem, 2000). Malaysia is the first country to implement dual banking system i.e. Islamic and conventional banking, in 2013 there were 17 Islamic banks comprised of 6 foreign and 11 domestic banks (Muda et al., 2013). The legitimization of any Islamic financial institution, and banking service in Malaysia is served by the Shariah advisory council, that is ruled by the central bank of Malaysia i.e. Bank Negara Malaysia.

The major problems and challenges regarding Islamic banking in Malaysia are the products proposed by Islamic banks in Malaysia, which are not fully embraced and taken by the customers widely, the major reason for it is the deficiency of intellectual and knowledgeable workers by Islamic banks in the main projects (Samad et al., 1999). Islamic banks in Malaysia are using some concepts which are in contrast with the sharia law, such as, Bay-al-Dayn and Dawa to ajjal, many of the Middle East Islamic scholars disagree with the scholar of Islamic banking in Malaysia upon implication of these principles (Haroon, 2000). Malaysia is placed second, with a global Sukuk share of $31 \%$ in 2007 (New Horizon, 2008).

Chong (2009) carried out a study on Islamic banking in Malaysia and found that in theory Islamic banking is treated as profit loss sharing the PLS. but in reality there is no difference in the profit and loss of Islamic and conventional banks in Malaysia. Further he argues that the growth in Islamic banking in Malaysia is not due to the uniqueness of PLS mode but its due Islamic banking resurgence world wide. 


\subsection{U.A.E}

The First Islamic bank of U.A.E started in 1975 with the name Dubai Islamic bank, since then U.A.E is attracting more and more customer toward Shariah compliant products. Currently, Islamic banks operating in U.A.E collectively holds $10 \%$ of the total Islamic banking asset share.

United Arab Emirates (U.A.E) initiated the process of centralizing zakat collection, previously all the individuals used to pay by their own. Now, Mr. Abdullah Bin Aqeeda Al Mujairi secretary of the fund has announced that, all the domestic Islamic banks and institution has to pay $2.5 \%$ of the net operating capital. UAE is the marketplace leader in Sukuk with issue of 34\% of its share in 2007 (New Horizon, 2008).

\subsection{Kuwait}

Kuwait finance house (KFH) was incorporated in 1977 as the first Islamic bank of Kuwait, since 1980 KFH has broadened its network to Turkey, Bahrain, and Malaysia. The Islamic banks that are operating in Kuwait collectively possess $7.9 \%$ of the total global Islamic banking assets. Kuwait finance house KFH is the leader in research on Islamic banking and finance. KFH is also playing its role in overseas market, as a successful journey of KFH in Bahrain despite of many challenges is evident. Beside Bahrain KFH has some important project in the pipeline as it is also planning to get the highest market share in Saudi Arabia, KFH is also planning to enter Europe through Turkey.

Kuwait Islamic banking assets in 2013 noticed a rapid and satisfactory increase of $8.7 \%$, along with $11 \%$ increase in Islamic finance. Out of Kuwait total banking assets, the Islamic banks are accounted for $43 \%$ of the total banking inside the country. Hartley (2014) said that the growth portrayed by Islamic banking and finance in Kuwait is in on the right track. Therefore, with such strong back and satisfactory growth in Islamic banking and finance will surely put Kuwait the market leader in Islamic banking in the near future.

\section{Objectives of the Study}

1) To examine the bankruptcy profile of the top five Islamic banking countries.

2) To examine the individual performance indicators that has significant impact on bankruptcy profile.

Note: Bankruptcy is used as a proxy for evaluation of economic sustainability.

\section{Methodology}

\subsection{Bankruptcy Model}

In order to predict bankruptcy of firms and banks many bankruptcy detection models are developed. The pioneer work in the area of bankruptcy was initially carried out by Beaver (1966) using accounting ratios. However Beaver's model was criticized on the basis of its univariate nature i.e. it could use only one variable at a time while predicting corporate distress.

Altman (1968) advanced beaver's model by introducing four more famous variables in that, Altman for the first time used multiple discriminant analysis MDA technique, according to MDA a collective analysis of all variables can be seen. Altman divided the sample in bankrupt and non bankrupt group, the model used financial characteristics i.e. accounting ratio and could predict bankruptcy five year prior to bankruptcy. This model became the famous bankruptcy model due to its simple understanding and accuracy. Altman model was recorded 94\% accurate in finding bankruptcy. Deakin (1972) used the same four variables those of Beaver's but applied them in different concept i.e. In multivariate perspective and achieved higher accuracy (Kiriakopoulos et al., 2014).

Altman et al. (1977) developed a Zeta model for diagnosing bankruptcy using seven financial ratios. The study used the sample of 53 failed and 58 non failed companies. The Zeta model was reported $96 \%$ accurate overall. Ohlson (1980) tried to offset the limitations of earlier Altman (1968), Altman et al. (1977) and Beaver's (1966) model by introducing logistic regression model for predicting bankruptcy. Later, on Altman (2000) by revisiting the initial Z-score model made it functional for service firms like the banks as well. The coefficients of the variables were change along with the elimination of variable $x 5$ i.e. sales/ Total assets, because the service firms don't have sales. The new Altman z-score model for service firms like the banks etc. shaped as:

$$
Z=6.56 x_{1}+3.26 x_{2}+6.72 x_{3}+1.05 x_{4}
$$

Tsai (2009) Said that features selection is very important step in increasing the bankruptcy prediction, further more he portrayed five well known features selection methods that are used in bankruptcy, i.e. Correlation matrix, t-test, stepwise regression, factor analysis (FA) and principle component analysis (PCA), and neural network. Pompe et al. (2005) studied the bankruptcy aspect of several small and medium firm and found that ratios have an enormous 
power in predicting bankruptcy. Mossman (1998) studied four bankruptcies models based on financial statement data, the division of the models include, cash flow model of (Aziz et al., 1988), market adjusted return's model of (Clark et al., 1983), standard deviation model of (Aharony et al., 1980), and ratios model of (Altman 1968). The results indicated that all the models were statically important one year prior to bankruptcy. However (Altman's ratio) model was recorded the most effective and efficient model in explaining bankruptcy. Looking at the efficiency and superiority of Altman model in the bankruptcy literature this study also selected Altman model.

\subsection{Model Used in This Study (Altman Model for Service Firms, 2000)}

$$
Z=6.56 X_{1}+3.26 X_{2}+6.72 X_{3}+1.05 X_{4}
$$

Altman model is a linear model composed of four ratios weighted with different coefficient. This model can predict the bank failure 5 years prior to bankruptcy with $95 \%$ accuracy. In the above model more Weightage of 6.72 is given to $\mathrm{X} 3$, followed by X1, X2, and X4, respectively. This model has a remarkable ability for accuracy in finding the financial health of the business and the probability of default (PD) (Altman, 2000). Kyriazopoulos et al., (2014) studied the bankruptcy of 6 Greek cooperative banks by using Altman Z-score, the study suggested that the banks failed due to lack of liquidity, and reported the model very accurate. Sharma et al. (2013) applied Altman model on Indian Banking Industry and found the model 70\% accurate in predicting bankruptcy. Chieng (2013) applied Altman model on 4 distressed and non-distressed Euro-zone banks and found that Altman model has $100 \%$ accuracy in finding financial distress of banks 5 year prior to failure. Mamo (2011) in his PH.D thesis applied Altman model on 43 commercial banks of Kenya, In case of failed and non-failed firms the model was reported $80 \%$ and $90 \%$ accurate respectively.

\subsection{Explanatory Variables}

$\mathrm{X} 1=$ Working Capital / Total Assets.

This ratio measures the liquid assets relative to total assets; working capital is the difference between current assets and current liabilities. Liquidity problem is faced by the banks due to excess withdrawal from (CASA) current account \& saving account, which are the main source of firm's survival in the time of trouble.

\section{$\mathrm{X} 2=$ Retained Earnings / Total Assets.}

This ratio measures the cumulative profitability of the firm, higher the profitability safer is the firm. However, age of the firm plays an important role in determining this ratio, generally the retained earnings is zero or negative in the early years of the firms business.

X3 = Earnings before Interest and Taxes / Total Assets.

EBIT means operating income. This ratio shows how productive a company is, in generating its earnings, relative to its size Altman found that this variable outperformed the rest continuously while designing the model, that's why the highest weighted of 6.72 , is given to this ratio. In Islamic banks EBIT is substituted with profit before zakat and taxes.

X4 = book value of Equity / Book Value of Total Liabilities

The book value of equity is the difference between the firm's total assets and its total liabilities. Technically, this ratio is used to check the insolvency of the firm.

Table 3. Zones of discriminations according to Z-score (for service firms)

\begin{tabular}{ll}
\hline $\mathrm{Z}>2.9$ & Safe Zone \\
\hline $1.23<\mathrm{Z}<2.9$ & Grey Zone \\
$\mathrm{Z}<1.21$ & Distress Zone \\
\hline
\end{tabular}

Source: Altman (2000).

According to Altman model of service firms if the result of z-score is greater than 2.9 the firm is recorded in safe zone, if it is below 1.21 the firm is in distress zone. However, if the value of $z$-score if found between 1.23 and 2.9 the firm is rated in grey zone, and grey zone means that, the firm can go either side i.e. safe or in distress zone consisting of its future performances. 


\subsection{Sampling Design}

Table 4. Breakdown of the global Islamic banking assets by country in percentage

\begin{tabular}{lll}
\hline S.N & Country & Share (USD1.1 Trillion) \\
\hline 1 & Iran & 39.7 \\
2 & Saudi Arabia & 13.7 \\
3 & Malaysia & 09.8 \\
4 & U.A.E & 09.1 \\
5 & Kuwait & 09.0 \\
6 & Qatar & 04.1 \\
7 & Turkey & 02.7 \\
8 & Bahrain & 02.3 \\
9 & Indonesia & 01.5 \\
10 & Egypt & 01.3 \\
11 & Sudan & 01.1 \\
12 & Others & 05.6 \\
13 & Total & $\mathbf{1 0 0 . 0}$
\end{tabular}

Source: Global Islamic forum 2012: Bridging economies introductory session and GIFF report page. 05 .

The above Table 4 highlights the shares of individual countries towards global Islamic banking assets. Top five countries account for about 80 per cent of the total assets with regard to global Islamic banking. These countries are Iran, Saudi Arabia, Malaysia, U.A.E, and Kuwait, and hence, through the judgmental sampling method, the study adopted the five countries for empirical testing on bankruptcy.

Table 5. List of selected Islamic banks from top five Islamic banking countries

\begin{tabular}{llll}
\hline No & Bank Details & Commencement & Status \\
\hline Iran & & & \\
\hline 1 & Saman Bank & 2002 & Domestic \\
3 & Karafarin Bank & 2001 & Domestic \\
4 & Sina Bank & 1985 & Domestic \\
5 & Bank Saderat Iran & 1980 & Domestic \\
\hline Saudi Arabia & 1979 & Domestic \\
\hline 6 & Al Baraka Investment \& Development Co & 1982 & \\
7 & Bank Al-Jazeera & 1975 & Domestic \\
8 & Islamic development bank & 1975 & Domestic \\
9 & Al-Rajhi bank of Saudi Arabia & 1957 & Domestic \\
10 & NCB & 1953 & Domestic \\
\hline Malaysia & & Domestic \\
\hline 11 & Standard Chartered Saadiq Berhad & 2008 & \\
12 & Alliance Islamic Bank & 2008 & Foreign \\
13 & Public Islamic Bank & 2008 & Domestic \\
14 & Hong Leong Islamic Bank & 2008 & Domestic \\
15 & Affin Islamic Bank Berhad & 2006 & Foreign \\
16 & AL-Rajhi Banking \& Investment Co & 2006 & Domestic \\
17 & Kuwait Finance House Malaysia & 2005 & Domestic \\
18 & RHB Islamic Bank & 2005 & Foreign \\
19 & CIMB Islamic Bank & 2003 & Domestic \\
20 & Bank Muamalat & 1999 & Domestic \\
21 & HSBC Ammnah & 1994 & Domestic \\
22 & Bank Islam & 1983 & Domestic \\
\hline U.A.E & & 2009 & Domestic \\
\hline 23 & Al Hilal Bank & & \\
\hline & & & \\
\hline
\end{tabular}




\begin{tabular}{llll}
\hline 24 & Attijari Al Islami & 2008 & Domestic \\
25 & Emirates Islamic Bank & 2004 & Domestic \\
26 & Sharjah Islamic bank & 2004 & Domestic \\
27 & Abu Dhabi Islamic Bank & 1988 & Domestic \\
28 & Dubai Islamic Bank & 1975 & Domestic \\
\hline Kuwait & & \\
\hline 29 & Al Ahli bank Kuwait & 2008 & Domestic \\
30 & Kuwait international bank & 2007 & Domestic \\
31 & Al-Rajhi Islami Bank of Kuwait & 2006 & Domestic \\
32 & Boubyan Bank & 2004 & Domestic \\
33 & Kuwait Finance House & 1977 & Domestic \\
\hline
\end{tabular}

Source:http://www.wdibf.com/islamic_banks.html; http://wiki.islamicfinance.de/index.php/Islamic_financial_institutions.

\subsection{Data Collection}

The study adopted secondary data which mainly involved financial data over the period 2009-2013. As for this purpose, annual reports of all the selected Islamic banks were used with regard to the requirements of the study. Financial data that were obtained from annual reports were also cross-referenced with the world data base for Islamic banking and finance and Islamic finance wiki.

\subsection{Hypothesis Development}

The first objective is to examine the bankruptcy profile of the top five Islamic banking countries. As different countries tend to differ on the performance of Islamic banking and sustainability, hence, the following hypothesis is developed.

$\mathbf{H}_{1}$ : Islamic banks of top five countries do differ on bankruptcy exposures.

The second objective is to examine the individual performance indicators that have significant impact on bankruptcy profile. The Altman Model argues that liquidity, profitability, productivity and insolvency are the four measures used to detect the sustainability of those banks through their scores on bankruptcy. However, further verification may be required to strengthen and confirm the effect of the four components, i.e. Liquidity, profitability, productivity and insolvency with the level of bankruptcy exposure faced by Islamic banks. This would enable the researcher to understand the relevance of the four measures in the context of bankruptcy. Thus, the following hypotheses are developed;

$\mathbf{H}_{2:} \mathbf{H}_{1}$ : Performance indicators are significantly correlated with bankruptcy exposure.

$\mathbf{H}_{2 \mathbf{a}}: \mathbf{H}_{1:}$ liquidity is significantly correlated with bankruptcy exposure.

$\mathbf{H}_{2 \mathbf{b}}: \mathbf{H}_{1}$ : Profitability is significantly correlated with bankruptcy exposure.

$\mathbf{H}_{2 \mathbf{c}}: \mathbf{H}_{1}$ : Productivity is significantly correlated with bankruptcy exposure.

$\mathbf{H}_{2 \mathbf{2}} \mathbf{H}_{1}$ : Insolvency is significantly correlated with bankruptcy exposure

\section{Results and Discussions}

Table 6. Z-Score of all selected Islamic banks across the five countries over the period 2009-2013

\begin{tabular}{|c|c|c|c|c|c|c|c|}
\hline S.N & Kuwait & 2009 & 2010 & 2011 & 2012 & 2013 & Average \\
\hline 1 & Al-Ahli Bank & 0.13 & 0.19 & 0.19 & 0.22 & 0.21 & 0.19 \\
\hline 2 & Al-Rajhi Bank & 2.17 & 1.85 & 1.67 & -- & -- & 1.90 \\
\hline 4 & KFH & 1.23 & 1.02 & 0.91 & 0.91 & 1.17 & 1.05 \\
\hline 5 & Kuwait international Bank & 1.07 & 1.40 & 1.53 & 1.48 & 1.39 & 1.37 \\
\hline 6 & Abu Dhabi Islamic Bank & 1.48 & 1.68 & 1.62 & 1.75 & 1.37 & 1.58 \\
\hline 7 & Al-Hilal Bank & 0.81 & 0.68 & 0.74 & 0.85 & 1.12 & 0.84 \\
\hline 8 & Attijari Al Islami & 4.40 & 4.74 & 4.80 & 1.87 & -- & 3.95 \\
\hline 9 & Dubai Islamic Bank & 1.30 & 1.33 & 1.07 & 1.06 & 2.01 & 1.35 \\
\hline 10 & Emirates Islamic Bank & 1.54 & 1.24 & 1.49 & 0.99 & 1.27 & 1.31 \\
\hline
\end{tabular}




\begin{tabular}{|c|c|c|c|c|c|c|c|}
\hline 11 & Sharjah Islamic bank & 2.16 & 2.11 & 2.00 & 1.97 & 1.70 & 1.99 \\
\hline \multicolumn{8}{|c|}{ Saudi Arabia } \\
\hline 12 & AL-Baraka Investment and development Co & 8.35 & 8.36 & 7.44 & 7.38 & 6.89 & 7.68 \\
\hline 13 & Al Jazeera Bank & 1.39 & 1.28 & 1.30 & 1.09 & 1.05 & 1.22 \\
\hline 14 & NCB & 1.04 & 1.01 & 1.06 & 1.06 & 1.07 & 1.05 \\
\hline 15 & Islamic development bank & 6.64 & 7.53 & 6.16 & 5.69 & -- & 6.51 \\
\hline 16 & Al-Rajhi bank Saudi Arabia & 1.90 & 1.56 & 1.42 & 1.22 & 1.23 & 1.47 \\
\hline \multicolumn{8}{|c|}{ Iran } \\
\hline 17 & Bank Maskan & 0.63 & 1.12 & 0.87 & 0.24 & - & 0.71 \\
\hline 18 & Bank Saderat Iran & 0.24 & 0.18 & 0.33 & 0.02 & 0.65 & 0.28 \\
\hline 19 & Karafarin Bank & 2.17 & 5.07 & 1.95 & 1.51 & 1.21 & 2.38 \\
\hline 20 & Saman Bank & 6.15 & 7.03 & 6.30 & 5.94 & -- & 6.36 \\
\hline 21 & Sina Bank & 0.43 & 0.73 & 0.75 & $\mathbf{0 . 5 3}$ & 0.84 & 0.66 \\
\hline \multicolumn{8}{|c|}{ Malaysia } \\
\hline 22 & Affin Islamic Bank Berhad & 0.75 & 0.69 & 0.55 & 0.51 & 0.44 & 0.59 \\
\hline 23 & Al Rajhi Banking \& Investment Co & 0.69 & 0.54 & 0.40 & 0.33 & -- & 0.49 \\
\hline 24 & Alliance Islamic bank & 0.93 & 0.87 & 0.76 & 0.69 & 0.65 & 0.78 \\
\hline 25 & Bank Muamalat & 0.81 & 0.76 & 0.71 & 0.55 & 0.61 & 0.69 \\
\hline 26 & CIMB Bank & 4.91 & 4.64 & 3.59 & 3.19 & 3.53 & 3.97 \\
\hline 27 & Hong Leong Islamic Bank & 0.95 & 1.04 & 0.70 & 0.66 & 0.65 & 0.80 \\
\hline 28 & HSBC Ammnah & 0.82 & 0.96 & 0.53 & 0.80 & 0.82 & 0.79 \\
\hline 29 & KFH Malaysia Berhad & 1.83 & 1.18 & 0.96 & 0.67 & 1.19 & 1.17 \\
\hline 30 & Public Islamic Bank & 0.61 & 0.72 & 0.55 & 0.62 & 0.53 & 0.61 \\
\hline 31 & RHB Islamic Bank & 0.77 & 0.62 & 0.47 & 0.54 & -- & 0.60 \\
\hline 32 & Standard Chartered Saadiq BHD & 0.84 & 1.17 & 0.89 & 0.50 & 0.003 & 0.68 \\
\hline 33 & Bank Islam & 0.32 & 0.63 & 0.48 & 0.58 & 0.55 & 0.51 \\
\hline
\end{tabular}

The above table 6 is showing the results of Z-score 2009-2013 of all the 33 selected Islamic banks from top five Islamic banking countries i.e. Iran, Saudi Arabia, Malaysia, Kuwait and U.A.E. the five year average z-score is also calculated.

Table 7. Bankruptcy profile of top five Islamic banking countries \%

\begin{tabular}{|c|c|c|c|c|c|c|c|}
\hline Country & Status & $2009 \%$ & $2010 \%$ & $2011 \%$ & $2012 \%$ & $2013 \%$ & Mean \% \\
\hline \multirow[t]{3}{*}{ Kuwait } & Bankrupt & 60 & 40 & 4 & 50 & 50 & 48 \\
\hline & Grey zone & 40 & 60 & 60 & 50 & 50 & 52 \\
\hline & Non-bankrupt & 00 & 00 & 00 & 00 & 00 & 00 \\
\hline \multirow[t]{3}{*}{ U.A.E } & Bankrupt & 17 & 17 & 33 & 50 & 40 & 31 \\
\hline & Grey zone & 67 & 67 & 50 & 50 & 60 & 59 \\
\hline & Non-bankrupt & 17 & 17 & 17 & 00 & 00 & 12 \\
\hline \multirow[t]{3}{*}{ Saudi } & Bankrupt & 20 & 20 & 20 & 40 & 50 & 29 \\
\hline & Grey zone & 40 & 40 & 40 & 20 & 25 & 32 \\
\hline & Non-bankrupt & 40 & 40 & 50 & 40 & 25 & 39 \\
\hline \multirow[t]{3}{*}{ Iran } & Bankrupt & 60 & 60 & 60 & 60 & 100 & 68 \\
\hline & Grey zone & 20 & 00 & 20 & 20 & 00 & 12 \\
\hline & Non-bankrupt & 20 & 40 & 20 & 20 & 00 & 20 \\
\hline \multirow[t]{3}{*}{ Malaysia } & Bankrupt & 83 & 92 & 92 & 90 & 90 & 89 \\
\hline & Grey zone & 08 & 00 & 00 & 00 & 00 & 02 \\
\hline & Non-bankrupt & 08 & 09 & 10 & 10 & 10 & 09 \\
\hline \multirow[t]{3}{*}{ Over all } & Bankrupt & 48 & 46 & 47 & 58 & 66 & 53 \\
\hline & Grey zone & 35 & 33 & 34 & 28 & 27 & 31 \\
\hline & Non-bankrupt & 17 & 21 & 19 & 14 & 07 & 16 \\
\hline \multirow[t]{3}{*}{ ANOVA } & & & & & & & Overall \\
\hline & F-value & 2.7 & 2.0 & 3.1 & 3.0 & 3.0 & 14.90 \\
\hline & P-value & 0.06 & 0.12 & 0.03 & 0.03 & 0.04 & 0.000 \\
\hline
\end{tabular}


The above Table 7 snapshot the bankruptcy rate of top five Islamic banking countries with regards to selected banks. Malaysia is the third largest Islamic banking figure with total of 20 per cent global Islamic banking assets but the bankruptcy rate of Malaysian banks is recorded very high i.e. 89 per cent followed by Iran 68 per cent., Kuwait 48 per cent, U.A.E 31 per cent, however, Saudi Arabian Islamic banks registered the lower bankruptcy rate in the selected sample of banks with only $29 \%$.

Table 8. Top five countries' ranking on performance indicators overall

\begin{tabular}{lllllll}
\hline S.N & Particular & Liquidity & Profitability & Productivity & Insolvency & z-score \\
\hline 1 & Country Average Ratio & & & & & \\
2 & Saudi Arabia & 2.28 & 0.05 & 0.18 & 1.07 & 3.59 \\
3 & Iran & 1.64 & 0.06 & 0.28 & 0.09 & 2.08 \\
4 & U.A.E & 1.18 & 0.05 & 0.16 & 0.42 & 1.84 \\
5 & Kuwait & 0.99 & 0.01 & 0.20 & 0.37 & 1.57 \\
6 & Malaysia & 0.48 & 0.02 & 0.11 & 0.34 & 0.97 \\
7 & Overall Average Ratio & 1.22 & 0.03 & 0.19 & 0.46 & 1.74 \\
7 & Countries' Ranking & & & & & Sustainability \\
8 & Saudi Arabia & 1 & 2 & 3 & 1 & 1 \\
9 & Iran & 2 & 1 & 1 & 5 & 2 \\
10 & U.A.E & 3 & 3 & 4 & 2 & 3 \\
11 & Kuwait & 4 & 5 & 2 & 3 & 4 \\
12 & Malaysia & 5 & 4 & 5 & 4 & 5 \\
\hline
\end{tabular}

The above table 8 shows the overall performance of the top five Islamic banking countries on the basis of performance indicators i.e. X1 liquidity, X2 profitability, X3 productivity, and X4 insolvency and on Z-score. Malaysian Islamic banks registered an overall low z-score rate of 0.97 due to the inefficient performance in liquidity, profitability, productivity, and insolvency ratios as Malaysia is on 5th position in liquidity and productivity, however on profitability and insolvency Malaysia registered 4th place in the sustainability profile list. Overall Saudi Arabian banks performed better as it registered 1st position on three indicators.

On the basis of average Z-score Saudi Arabian banks with 3.59 z-score have top the sustainability list followed by Iran, U.A.E, Kuwait and Malaysia on 2nd, 3rd, 4th, and 5th, position respectively. Overall average liquidity and insolvency ratios are satisfactory with 1.22 per cent and 0.46 per cent respectively. However, the average cumulative profitability and assets productivity ratios are found unsatisfactory with and average of 0.03 and 0.19 respectively.

Table 9. Regression results for Islamic banks bankruptcy

\begin{tabular}{lllll}
\hline Model & Coefficient & t-stat & Tolerance & VIF \\
\hline Constant &.-142 & $-2.106^{*}$ & - & - \\
Liquidity & .980 & $103.539^{* *}$ & .671 & 1.491 \\
Profitability & .038 & .934 & .784 & 1.275 \\
Productivity & 1.048 & $47.211^{* *}$ & .976 & 1.025 \\
Insolvency & 1.055 & $91.316^{* *}$ & .559 & 1.789 \\
Bank Size & .009 & $2.364^{*}$ & .937 & 1.067 \\
F-test: $10567^{* *}$ & & & & \\
Adjusted R2 $=98 \%$ & & & & \\
Dependent Variable: Z-score & & & & \\
\hline
\end{tabular}

Note. * Represents the significance of level at $0.05 * *$ Represents the significance of level at 0.01 .

$$
\text { Z-score }=-0.142+0.980_{\text {Liq }}+0.038_{\text {Prof }}+1.048_{\text {Prod }}+1.055_{\text {Insol }}+0.009_{\text {Size }}+\varepsilon
$$

The regression test is conducted to examine the impact of performance indicators on bankruptcy scores. This is to further verify the arguments put forward by Altman (2000). Table 9 presents the regression results in which the $\mathrm{R}^{2}$ is 0.99 . To detect multicollinearity in the model tolerance factor and VIF variance inflation factors are used. The value of VIF greater than 10 and that of tolerance factor close to zero shows the problem of 
multicollinearity. In line of that no sign of multicollinearity is detected in the model.

The result shows that all the performance indicators i.e. liquidity, productivity, insolvency and bank size have a significant correlation with bankruptcy except profitability, and hence this study has disapproved the argument that only profitability is enough to avoid bankruptcy. The results are consistent with that of (Husna et al., 2012). In the above Table, X1, X3, X4 are very significant at 0.000 and hence, H2a, H2c and H2d are supported. Hypothesis $\mathrm{H} 2 \mathrm{~b}$ is not supported. Therefore, profitability does not really explain the banks' bankruptcy exposures in the case of Islamic banking industry.

\section{Conclusions}

After achieving both the objectives of the study it is concluded that the sustainability profile of Islamic banks is not preserved efficiently, according to Altman model the overall bankruptcy rate of selected Islamic banks from top five Islamic banking countries by global Islamic banking assets is recorded 53 per cent which is very significant, while, Malaysian Islamic banks registered the highest bankruptcy rate of 89 per cent, and Saudi Arabian banks retained the lowest bankruptcy rate of 29 per cent. While evaluating the sustainability profile of Islamic banks this study came across the findings that the average productivity and profitability ratios of Islamic banks are not very high i.e. $0.19 \%$ and $0.03 \%$ respectively, in case of any financial distress these two ratios will be the main contributor towards the distress. However, insolvency and liquidity of Islamic banks are found better on average i.e. $0.46 \%$ and $1.22 \%$ respectively.

For maintaining economic sustainability the banking industry considers profitability the main factor and although Islamic banks are consider more profitable than conventional banks. However, in Islamic banking perspective the argument has been disapproved, because the p-value of profitability in regression model is found insignificant and hence proved that profitability is insignificant with bankruptcy exposure. Beside profitability, the other performance indicators i.e. Productivity, liquidity, insolvency are found to have a significant impact in maintaining strong sustainability of Islamic banks.

\subsection{Limitation of the Study}

The sustainability evaluating model used in this study required retained earnings, while retained earning is directly linked with the age of firm. However, majority of the Malaysian and Kuwaiti Islamic banks are incorporated in mid 2000, the small age of these banks lead towards lower or negative retained earning, ultimately reduced their sustainability in the evaluation process.

\subsection{Suggestions for Further Studies}

Altman model used in this study use only micro factors. To further explore the sustainability of Islamic banking industry a separate bankruptcy continuum model composed of micro, macro, and Islamic bank's structural variables can be developed. Because Islamic bank do not have its own separate sustainability evaluating model, the existing conventional models are used with minor changes (Husna et al., 2012).

\section{References}

Abdullah, A. A., Sidek, R., \& Adnan, A. A. (2012). Perception of non-Muslims customers towards Islamic banks in Malaysia. International Journal of Business and Social Science, 3(11), 151-163.

Aharony, J., Jones, C., \& Swary, I. (1980). An analysis of risk characteristics of corporate bankruptcy using capital market data. Journal of Finance, 35, 1001-1016. http://dx.doi.org/10.1111/j.1540-6261.1980.tb03516.x

Altman, E. I. (1968). Financial ratios discriminant analysis and the prediction of corporate bankruptcy. The Journal of Finance, 23(4), 589-609. http://dx.doi.org/10.1111/j.1540-6261.1968.tb00843.x

Altman, E. I. (1984). The success of business failure prediction models: An international survey. Journal of Banking \& Finance, 8(2), 171-198. http://dx.doi.org/10.1016/0378-4266(84)90003-7

Altman, E. I. (2000). Predicting financial distress of companies: Revisiting the Z-score and Zeta Models. Journal of Banking \& Finance.

Altman, E. I., Haldeman, R. G., \& Narayanan, P. (1977). ZETA Analysis: A New Model to identify Bankruptcy Risk of Corporations. Journal of Banking and Finance, 1(1), 29-54. http://dx.doi.org/10.1016/0378-4266(77)90017-6

Anwar, M. (1992). Islamic banking in Iran and Pakistan: A comparative study. The Pakistan Development Review, 1089-1097.

Aziz, A., Emanuel, D. C., \& Lawson, G. H. (1988). Bankruptcy prediction-an investigation of cash flow based 
$\begin{array}{lllll}\text { models. } & \text { Journal } & \text { Management } & \text { Studies, } & \text { 25(5), }\end{array}$ http://dx.doi.org/10.1111/j.1467-6486.1988.tb00708.x

Beaver, W. H. (1966). Financial ratios as predictors of failure. Journal of Accounting Research, 4, 71-111. http://dx.doi.org/10.2307/2490171

Beck, T., Demirgüç-Kunt, A., \& Merrouche, O. (2013). Islamic vs. conventional banking: Business model, efficiency and stability. Journal of Banking \& Finance, 37(2), 433-447. http://dx.doi.org/10.1016/j.jbankfin.2012.09.016

Brown, K. (2003). Islamic banking comparative analysis. The Arab Bank Review, 5(2), 43-50.

Chenguel, M. B. (2014). Islamic Banking and the Last Financial Crisis. International Journal of Research in Applied Sciences, 3(3), 29.

Chieng, J. R. (2013). Verifying the Validity of Altman's Z' Score as a Predictor of Bank Failures in the Case of the Eurozone. Submitted to the National College of Ireland.

Chong, B. S., \& Liu, M. H. (2009). Islamic banking: Interest-free or interest-based? Pacific-Basin Finance Journal, 17(1), 125-144. http://dx.doi.org/10.1016/j.pacfin.2007.12.003

Cihak, M., \& Hesse, H. (2010). Islamic banks and financial stability: An empirical analysis. Journal of Financial Services Research, 38(2-3), 95-113. http://dx.doi.org/10.1007/s10693-010-0089-0

Clark, T., \& Weinstein, M. (1983). The behavior of common stock of bankrupt firms. Journal of Finance, 38, 489-504. http://dx.doi.org/10.1111/j.1540-6261.1983.tb02257.x

Deakin, E. B. (1972). A discriminant analysis of predictors of business failure. Journal of Accounting Research, 167-179. http://dx.doi.org/10.2307/2490225

Derbel, H., Bouraoui, T., \& Dammak, N. (2011). Can Islamic Finance Constitute a Solution to Crisis? International Journal of Economics and Finance, 3(3), 75. http://dx.doi.org/10.5539/ijef.v3n3p75

Haron, S. N. A. (2000). Islamic banking system in Malaysia Center for Middle Eastern Studies (pp. 155-163). Harvard University.

Haroon, S. (2004). Determinants of Islamic bank's profitability. Global Journal of Finance and Economics, 1(1).

Hartley, R. (2014). Kuwait progress toward Islamic banking vision. Published in, The banker 01-pril-2014.

Husna, H. N., Rahman, R. A., Graff, M., Mirani, M. A., Shah, S. M. M., Alani, J., \& Brezinova, O. (2012). Financial Distress-Detection Model for Islamic Banks. International Journal of Trade, Economics \& Finance, 3(3).

Iqbal, M., \& Molyneux, P. (2005). Thirty Years of Islamic Banking: History, Performance, and Prospects.

Isaac, W. M., Archer, S., Karim, R. A. A., Packer, F., Shek, J., Zhu, H., \& Poenisch, H. (2014). Seacen Financial Stability Journal, 3.

Jeucken, M. H., \& Bouma, J. J. (1999). The changing environment of banks. Greener Management International, (27), 20-35.

Kaleem, A. (2000). Modeling monetary stability under dual banking system: The case of Malaysia. International Journal of Islamic Financial Services, 2(1), 21-42.

Keeble, J. J., Topiol, S., \& Berkeley, S. (2003). Using indicators to measure sustainability performance at a corporate and project level. Journal of Business Ethics, 44(2-3), 149-158.

Kumar, P., \& Ravi, V. (2007). Bankruptcy prediction in banks and firms via statistical and intelligent techniquesA review. European Journal of Operational Research, 180(1), 1-28. http://dx.doi.org/10.1016/j.ejor.2006.08.043

Kyriazopoulos, G. M. K. (2014). The Edward I. Altman's Model of Bankruptcy and the implementation of it on the Greek cooperative banks (pp. 423-436). 9th Annual MIBES International Conference.

León, P. (2001). Four pillars of financial sustainability. Nature Conservancy.

Magd, H. A., \& McCoy, M. P. (2014). Islamic Finance Development in the Sultanate of Oman: Barriers and Recommendations. Procedia Economics and Finance, 15, 1619-1631. http://dx.doi.org/10.1016/S2212-5671(14)00633-9

Mamo, A. Q. (2011). Applicability of Altman (1968) model in predicting financial distress of commercial banks in 
Kenya. PhD diss.

Mossman, C. E., Bell, G. G., Swartz, L. M., \& Turtle, H. (1998). An empirical comparison of bankruptcy models. Financial Review, 33(2), 35. http://dx.doi.org/10.1111/j.1540-6288.1998.tb01367.x

Muda, M., Shaharuddin, A., \& Embaya, A. (2013). Comparative Analysis of Profitability Determinants of Domestic and Foreign Islamic Banks in Malaysia. International Journal of Economics and Financial Issues, 3(3), 559-569.

New Horizon. (2008). Global perspective on Islamic banking and insurance. Issue No. 168 July- September 2008, Rajab- Ramadan 1429.

Ohlson, J. A. (1980). Financial ratios and the probabilistic prediction of bankruptcy. Journal of Accounting Research, 18(1), 109-131. http://dx.doi.org/10.2307/2490395

Olson, D., \& Zoubi, T. A. (2008). Using accounting ratios to distinguish between Islamic and conventional banks in the GCC region. The International Journal of Accounting, 43(1), 45-65. http://dx.doi.org/10.1016/j.intacc.2008.01.003

Pompe, P. P., \& Bilderbeek, J. (2005). The prediction of bankruptcy of small-and medium-sized industrial firms. Journal of Business Venturing, 20(6), 847-868. http://dx.doi.org/10.1016/j.jbusvent.2004.07.003

Rashid, M., \& Nishat, A. (2009). Disparity of Performance Indicators of Islamic Banks: Study on Bangladesh. International Journal of Business and Management, 4(8), 52. http://dx.doi.org/10.5539/ijbm.v4n8p52

Rennings, K., \& Wiggering, H. (1997). Steps towards indicators of sustainable development: Linking economic and ecological concepts. Ecological Economics, $20(1), \quad$ 25-36. http://dx.doi.org/10.1016/S0921-8009(96)00108-5

Safiullah, M. (2010). Superiority of conventional banks \& Islamic banks of Bangladesh: A comparative study. International Journal of Economics and Finance, 2(3), 199. http://dx.doi.org/10.5539/ijef.v2n3p199

Samad, A. M. K. (1999). The performance of Malaysian Islamic banks during 1984-1987: An exploratory study. International Journal of Islamic Financial Services, 1(3).

Sharma, N. M. (2013). Altman model and financial soundness of Indian banks. International Journal of Accounting and Finance, 55-60.

Telmoudi, F., Ghourabi, M. E., \& Limam, M. (2011). RST-GCBR-Clustering-Based RGA-SVM Model for Corporate Failure Prediction. Accounting, Finance and Management, 18(2-3), 105-120. http://dx.doi.org/10.1002/isaf.323

Tsai, C. F. (2009). Feature selection in bankruptcy prediction. Knowledge-Based Systems, 22(2), 120-127. http://dx.doi.org/10.1016/j.knosys.2008.08.002

Usman, A., \& Khan, M. K. (2012). Evaluating the financial performance of Islamic and conventional banks of Pakistan: A comparative analysis. International Journal of Business and Social Science, 3(7), 253-257.

World Islamic Banking Competitiveness Report. (2011-2012, 2013-2014).

Yudistra, D. (2004). Efficiency in Islamic banking: An empirical analysis of eighteen banks. Islamic Economic Studies, 12(1), 1-19.

\section{Notes}

Note 1. GABV is an independent network of around 25 banks along the world, working to promote ethical banking. The group retains more than $\$ 70$ billion for socioeconomic projects.

Note 2. After 2009 G-20 summit of London As successor of (FSF) financial stability forum, the (FSB) was established. It is an international body that monitors and recommend about the global financial system.

Note 3. The (GRI) Global reporting initiative is a non-profit organization formed by United States in 1997. It provides the standards and guideline for sustainability reporting

Note 4. SAMA Saudi Arabian Monetary Agency established on 1952 in Riyadh Saudi Arabia, it is an agency that acts like the central bank for Saudi Arabia. 


\section{Copyrights}

Copyright for this article is retained by the author(s), with first publication rights granted to the journal.

This is an open-access article distributed under the terms and conditions of the Creative Commons Attribution license (http://creativecommons.org/licenses/by/3.0/). 